\title{
COMPENSATION FOR DISTURBANCE UNDER THE BUSINESS TENANCIES (NI) ORDER 1996 - SOME QUERIES
}

\author{
Norma Dawson, Professor of Law, Queen's University Belfast*
}

The purpose of this short article is to highlight an apparent change in the law relating to compensation for disturbance of business tenants under the Business Tenancies (NI) Order 1996 ("the Order"), a change which was probably not intended and which could cost landlords substantial sums of money because it creates a major shift in the policy governing eligibility for compensation. At the end of the article, a second, more general, query relating to the same provision is also briefly explored.

\section{Compensation for disturbance of defaulting tenants?}

The business tenancies code has traditionally drawn a distinction between good and bad tenants. ${ }^{1}$ Business tenants who are in breach of their obligations have always remained vulnerable to forfeiture or ejectment, and these powers are expressly preserved by the Order, following the example of its predecessor, the Business Tenancies Act (NI) 1964 ("the 1964 Act"). ${ }^{2}$ They are also likely to encounter landlord opposition to the renewal of the tenancy on the basis of the first three statutory grounds of opposition, paragraphs (a) - (c) of article 12(1) of the Order. These three grounds refer to tenant default of one type or another. Furthermore, landlords who have successfully opposed renewal on any of the default grounds, have not incurred liability for compensation for disturbance, at least not under previous legislation. On the other hand, tenants who fulfil their tenancy obligations can expect to have a renewal of the tenancy, or suitable alternative accommodation, ${ }^{3}$ or compensation for disturbance if the landlord successfully opposes renewal on the basis of his need to recover possession of the premises in order to further his own legitimate domestic or economic interests. $^{4}$

In order to maintain this distinction, the statutory provision for compensation for disturbance under the 1964 Act contained a key phrase which expressly restricted the availability of compensation to those cases where the Lands Tribunal was precluded from making an order for the grant of a new tenancy:-

\footnotetext{
* I am grateful to Rosemary Carson, partner, Carson McDowell, for helpful comments on an earlier draft of this article. The views expressed here are my own.

1 See Government Policy on Leasehold Property in England and Wales (1953, Cmd 8713), para 43. This policy statement was followed by the enactment of the Landlord and Tenant Act 1954, Part II. In Northern Ireland, the Business Tenancies Act (NI) 1964 essentially adopted the same policy.

2 Article 8(1) of the Order; section 6(1) of the 1964 Act.

3 Article 12(1)(d) of the Order.

4 Article 23 and article 12(1)(e) - (h) of the Order.
} 
"by reason of any of the grounds specified in paragraphs (e), (f) and (g) of subsection (1) of section 10, and not of any grounds specified in any other paragraph of that section. ${ }_{5}$

The equivalent English provision, section 37(1) of the Landlord and Tenant Act 1954 ("the 1954 Act"), is couched in similar terms. Section 37 was amended in 1969 so that the right to compensation for disturbance could arise at two possible stages in the process. The first, identical to that referred to in section 19(1) of the 1964 Act, is where the landlord's opposition succeeds at hearing on any of the grounds specified in paragraphs (e) $-(\mathrm{g})$, and on no other grounds. The second situation, added in 1969, is where the landlord's notice states his opposition on any of the grounds specified to in paragraphs (e) - (g), and no other ground is specified in his notice or counter-notice, and the tenant either makes no application for a new tenancy or later withdraws his application. Although section 37 was extended in 1969 so that it now can apply at two different stages in the process, the key phrase - and not on any ground specified in any other paragraph - was expressly retained and governs each scenario.

When reform of the 1964 Act was first considered in the early 1990s, the Law Reform Advisory Committee for Northern Ireland (LRAC) at an early stage proposed an amendment which would bring the law in Northern Ireland into line with the change made to section 37(1) in England in 1969. The terms on which the change should be made were stated unambiguously in a LRAC Discussion Paper published in 1992.

"If this were adopted, the right to compensation would continue to be based on the landlord's opposition to renewal on grounds specified in section $10(1)(e),(f)$ and $(g)$, but it would arise not only where the Tribunal refuses a new tenancy on those grounds, but also where the tenant does not apply for a new tenancy or where he withdraws his application and agrees to quit the premises on the strength of the landlord's opposition on any of the three relevant grounds. There will be many cases where a tenant can make a realistic assessment of the strength of the landlord's case. Where, having done that, he is not inclined to apply to the tribunal for a new tenancy, he should not be compelled to do so merely in order to be able to assert a claim to compensation."6

Two years later, in the LRAC Report on Business Tenancies, ${ }^{7}$ the following recommendation was made.

"We therefore recommend that where the landlord's notice to determine or notice of opposition to a new tenancy relies upon the grounds in section $10(1)(e)$, $(f)$ or $(g)$ and no other grounds, and the tenant either does not apply for a new

5 Section 19(1) of the 1964 Act. Italics added.

6 LRAC, Discussion Paper No 3, A Review of the Law relating to Business Tenancies in NI, (1992, HMSO), para 8.2.2.

7 LRAC No 2, 1994 (HMSO). 
tenancy or applies and then withdraws his application, the tenant will have a right to compensation for disturbance." 8

This recommendation has been implemented in article 23(1) of the Order, remedying a serious deficiency of the 1964 Act. As one English judge has recently stated:

"The disturbance is suffered equally when ... the tenant withdraws his application for a new tenancy and a tenant in these circumstances is just as much entitled to his compensation." 9

When one considers the LRAC recommendation quoted above, and in particular the italicised words, there can be no doubt that the Committee did not intend to extend the right to compensation for disturbance to defaulting tenants whose conduct is a basis for landlord opposition on any of the grounds contained in paragraphs (a) - (c), or indeed to tenants who are offered suitable alternative accommodation under paragraph (d) of article 12(1) of the Order.

The difficulty is that the Order does not contain the words "and on no other grounds" or any equivalent formula. The failure to use a formula, tried and tested in the 1954 and 1964 Acts, to maintain a distinction between defaulting tenants and those who comply with the terms of their tenancy, first occurred in the Draft Order appended to the LRAC Report of 1994, and is repeated in the Order itself. This raises the question whether a defaulting tenant is now entitled to compensation for disturbance. Given the legislative history of the compensation provision and the omission of words deliberately used in the 1954 and 1964 Acts in order to prevent this result, it now appears that defaulting tenants can now claim compensation in the following circumstances:

(1) The landlord opposes renewal on the grounds specified, for example, in paragraphs (b) and (g) of article 12(1) of the Order. Paragraph (b) (persistent delay in paying rent) is a non-compensatory ground of opposition, whilst paragraph $(\mathrm{g})$ (landlord requires the premises for his own business or as his residence) gives rise to a potential entitlement to compensation for disturbance. Both grounds are established at the hearing and the Lands Tribunal either grants the landlord's tenancy application or refuses the tenant's tenancy application. In the event of refusal, under the 1964 Act, and currently in England and Wales, the tenant would not be entitled to compensation for disturbance on these facts. Under the Order, however, it appears that the defaulting tenant is entitled to compensation for disturbance, because the landlord relied on, and established, a compensatory ground of opposition, and despite the fact that the landlord also relied on, and established, a non-compensatory ground of opposition.

(2) As in (1), the landlord relies on the grounds contained in paragraphs (b) and $(g)$ of article $12(1)$, and the tenant fails to make a tenancy

8 Ibid, para 8.2.2. Italics added.

9 Bacchiocchi v Academic Agency Ltd [1998] 2 All ER 241, 251, per Ward LJ. This case concerned contracting out of compensation for disturbance, which is no longer possible in Northern Ireland under article 24(d) of the Order. 
application or later withdraws his tenancy application. In England and Wales, compensation for disturbance is not payable in these circumstances. Under the 1954 Act, it is necessary to defeat landlord opposition based on tenant default in order to be eligible for compensation for disturbance. If the tenant does not make, or later withdraws, an application for renewal, he inevitably remains ineligible for compensation. For this reason, a landlord may adopt the tactic of relying on one of the non-compensatory/default grounds in paragraphs (a) - (c) as well as one of the compensatory grounds in paragraphs (e) $(\mathrm{g})$, in order to put additional pressure on the tenant. ${ }^{10}$ In Northern Ireland, however, it appears that, on the facts outlined, the tenant is entitled to compensation for disturbance because the landlord relied in his notice on a compensatory ground, and despite the fact that he also relied on a non-compensatory ground.

The Lands Tribunal for Northern Ireland has interpreted article 23 of the Order in this way. In Age Concern v The Honourable The Irish Society, ${ }^{11}$ the landlord's notice to determine relied on paragraphs (c) and (f) of article 12(1). The parties entered into an agreement that the tenant would quit the premises and the landlord would pay the statutory compensation for disturbance. They could not agree on the allocation of costs. The tenant had made a tenancy application. The Tribunal held that the tenant's application had been unnecessary, as the right to compensation is secured as soon as the landlord relies on a compensatory ground of opposition, even though that is coupled with a non-compensatory ground of opposition. As the application was unnecessary, the Tribunal made no order as to costs.

For defaulting tenants to be eligible for compensation for disturbance is contrary to long-established policy. It is also clearly inconsistent with the intention of the Law Reform Advisory Committee as expressed in the 1994 Report, and for that reason, a court might be inclined to adopt a "purposive" construction and interpret article 23(1) as if the missing words were implied. The problem with such an approach would seem to be that these words were actually present in the 1964 Act and are actually present in the 1954 Act. Their absence from the face of article 23(1) is, accordingly, difficult to overlook by a process of benign interpretation.

The question, therefore, arises whether article 23(1) should be amended to make it clear that compensation for disturbance is payable only when the landlord establishes at hearing any of the compensatory grounds and no other grounds, or where he relies in his notice on any of those grounds and no other grounds, and the tenant does not make, or later withdraws, a tenancy application. As we have seen, the LRAC Report of 1994 leaves no room for doubt as to the Committee's intentions, which have not been realised in the 1996 Order. On the other hand, an ex post facto justification might be found for not amending the Order. An argument could be advanced for maintaining the current wording in order to prevent landlords deliberately defeating compensation claims by adding unfounded non-compensatory grounds to well-founded compensatory grounds of opposition. This point of view is tenable at least where, on the strength of the landlord's notice, a

10 See Haley, The Statutory Regulation of Business Tenancies (2000), para 5.32.

11 BT/95/2000, 9 December 2001. 
tenant either does not make, or later withdraws, a tenancy application - in practice, this may prove to be the common case. Where, however, a case proceeds to a Tribunal hearing and a new tenancy is refused because the landlord has established both compensatory and non-compensatory grounds of opposition, the defaulting tenant's eligibility for compensation under the 1996 Order marks a significant change in policy, not heralded by the LRAC Report.

In light of the wording of article 23 and of the Tribunal's decision in the Age Concern case, the parties and their advisors must reflect this development in their estate management strategy. If the landlord believes that he can establish a ground of opposition based upon tenant default and also one of the compensatory grounds, he could decide to resist renewal solely on the non-compensatory ground in order to be confident of not incurring liability for compensation for disturbance. But could he at the same time be confident of successfully preventing renewal, given that the default grounds of opposition are at the discretion of the Lands Tribunal? ${ }^{12}$ Even where a ground of opposition based on tenant default is made out, the Tribunal has a discretion to grant a new tenancy. Thus, a landlord who relies solely on one of these grounds runs the risk of a new tenancy being granted, especially if the tenant has redeemed his position by the date of the hearing. The landlord will then have missed the chance to recover possession on other grounds such as those contained in paragraphs (f) or (g). Weighing his options in advance, a landlord may decide that recovery of possession is more important than avoiding liability for compensation for disturbance, and so choose to rely on both compensatory and non-compensatory grounds to ensure success in attaining his primary objective. Meanwhile, a tenant who makes a tenancy application believing that eligibility for compensation for disturbance depends upon defeating landlord opposition on noncompensatory grounds, does so at the risk of incurring unnecessary and irrecoverable costs.

\section{A more general issue of compensation for disturbance - what must be proved?}

As stated earlier, article 23(1) of the Order brings Northern Ireland law into line with English law in that a tenant need not pursue a tenancy application to the bitter end in order to establish an entitlement to compensation for disturbance. However, a rogue phrase has crept into article 23(1), which is not present in the equivalent English legislation. Article 23(1) is as follows:

\footnotetext{
"Where a landlord-

has served-

a notice to determine a tenancy to which this Order applies, or

in response to the tenant's request for a new tenancy, a notice under Article 7(6)(b) stating that he will oppose a tenancy application by the tenant,

and the notice states that a tenancy application by the tenant would or will be opposed, on any of the grounds specified in
}

12 See Dawson, Business Tenancies in Northern Ireland (1994), 125-30. 
sub-paragraphs (e), (f), (g), (h) and (i) of paragraph (1) of Article 12; and

either-

in consequence of the landlord's notice the tenant does not make a tenancy application or, if he has made such an application, withdraws it, or

on hearing a tenancy application by the landlord or a tenancy application by the tenant, the Lands Tribunal, on any of the grounds mentioned in sub-paragraph (a), grants the former application or dismisses the latter; and

the circumstances are such that paragraph (7) does not apply,

then, subject to the provisions of this Order, the tenant shall be entitled on quitting the holding to recover from the landlord by way of compensation a sum determined in accordance with the following provisions of this Article."13

The italicised words do not appear in the English legislation, which only requires proof of a chronological series of actual steps, including failure to apply or subsequent withdrawal. The question, therefore, arises whether the words, "in consequence of the landlord's notice", require additional proof from the tenant in order to establish eligibility for compensation, or whether it will be presumed that the tenant failed to make, or later withdrew, a tenancy application in consequence of the landlord's notice. If this is to be presumed, the words become otiose, unless, of course, the presumption is rebuttable. Article 23(1) would make sense without the highlighted words, and would also be consistent with the equivalent English provision and with the text of the LRAC Report of 1994. The question, therefore, lingers, are they intended to mean something? If causality has replaced mere chronology, what proof is required of the tenant in order to establish the right to compensation?

13 Italics added. 